to an acuminate apex with the upper basal segment usually auriculate; all segments terminating in one or more acuminate bristle-like tips; sori $1-8$ on each segment, large, 1-2 $\mathrm{mm}$. in diameter when fully mature, strongly confluent.

Type sheet No. 83121 in the Herbarium of the Canadian Geological Survey. Co-type collected at the same time and place sheet No. 2376 in my herbarium. Type locality, Elk River, Stratheona Park, Vancouver Island, British Columbia.

$P$. lonchitis, $P$. acrostichoides, and $P$. munitum are simply pinnate while the new Polystichum has its pinnae pinnnatifid the entire length of the frond. This characteristic, as well as its size, will also separate it from $P$. scopulinum and $P$. californicum whose "pinnae are partly pinnatifid below."

$P$. aculeatum and $P$. Braunii have large fronds and are fully bipinnate.

$P$. Lemmoni, the most closely related species, has the "pinnae closely placed, ovate, rounded at the ends, made up of 8-10 pairs of pinnules or divisions, beside the terminal one, obtuse, not armed, sori one or two to each pinnule" whereas in the new species the pinnae are not so closely placed, are not rounded at the ends, have 20-30 pinnules or divisions which are not obtuse, and which are fully armed with bristle like points, and which have 1-8 large confluent sori on each pinnule.

Kent State Normal School,

Kent, Ohio.

\title{
Notes on Nomenclature.
}

\section{WILLARD N. CLUTE.}

In the current number of The American Fern JourNAL, (page 75), I note a proposed new combination of Selaginella densa as Selaginella rupestris densa, and 
while such trifling combinations do not seem to me of much importance, for the sake of accuracy it may bc pointed out that this much combination has been previously made; at least the exact combination of words appears in "The Fern Allies of North America" (page 264 ) and in the treatment of Selaginella rupestris in the same volume (page 142) the fact that densa may be regarded as a form of rupestris is mentioned. Furthermore, in volume XVI of the Fern Bulletin (page 53) this same combination is again made with $S$. densa as a synonym. It strikes me, therefore, that this combination has been published as definitely as it ever needs to be.

The disposition to make much of these insignificant combinations is sometimes manifested in places where one would least expect to find it. For instance, in the new "Gray's Manual" (page 42) may be found the combination "Aspidium Goldianum variety celsum (Palmer) Robinson," and yet several years before this combination was published, the identical combination was made by another writer in "Our Ferns in Their Haunts" (page 315 ), with the slight exception that the word form was used in place of the word variety. The dictionaries make practically no difference in the significance of these two words and I am of the opinion that there is not sufficient difference to warrant anybody squeezing another name into the combination on such a pretext. It is to be hoped there is not, for if it is possible, there may be danger that some botanizer will trade forms for varieties or the reverse in every botanical name that will permit of it. Curiously enough in the combination mentioned above, where the specimen is first named it is spoken of both as a variety and a form. In passing it may be of interest to note the difference in spelling of the specific name of the fern in question. I have not the original description before me, but with- 
out consulting Hooker in the matter, it seems to me that the specific name should be Goldieanum. It may be true that Hooker wrote it Goldianum, but we have the right to correct the spelling of any wrongly spelled specific name and since Goldie spelled his name with a final "e" we ought to make the word Goldieanum. L. M. Underwood so used it in his books and he was a man not likely to go astray in such matters.

Still another instance of the change from form to variety in the author citation that may interest fern students may be found in Rhodora for May, 1913 (page 87). Here a form of Ophioglossum vulgatum called variety lanceolatum is renamed Ophioglossum vulgatum forma lanceolatum and this slight change, so slight that the average reader will have to look at it again to find a difference, is regarded as sufficient warrant for a change in the author citation. It may be possible that the systematist is so completely engrossed in the job as to fail to appreciate the absurdity of it all, but to the average individual this seems too petty for educated adults to engage in and I believe the time will come when the systematist will see the affair in the same light.

If we are to have differences in the writing of scientific names based on the slight differences in significance between form and variety, some of the scientists interested should give us an exact definition of each word as it applies in botany, so that the future work of naming may be simplified. At present we have been accustomed to write species with a generic and specific name, subspecies with a generic, specific, and subspecific name, and lesser forms with the word form or variety before them to signify that they are not subspecies. Then why this distinction between two words which mean the same thing?

Joliet, ILLINOIS. 


\section{$2 \mathrm{BHL}$ Biodiversity Heritage Library}

Clute, Willard Nelson. 1913. "Notes on Nomenclature." American fern journal 3, 118-120. https://doi.org/10.2307/1543806.

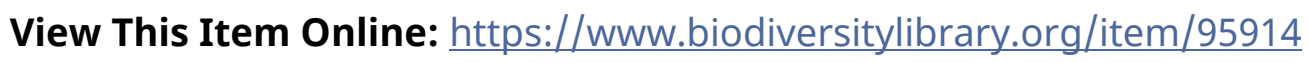

DOI: https://doi.org/10.2307/1543806

Permalink: https://www.biodiversitylibrary.org/partpdf/229968

\section{Holding Institution}

Missouri Botanical Garden, Peter H. Raven Library

\section{Sponsored by}

Missouri Botanical Garden

\section{Copyright \& Reuse}

Copyright Status: Public domain. The BHL considers that this work is no longer under copyright protection.

This document was created from content at the Biodiversity Heritage Library, the world's largest open access digital library for biodiversity literature and archives. Visit BHL at https://www.biodiversitylibrary.org. 